\title{
Ruthenium(II) complexes bearing pyridine-functionalized $N$-heterocyclic carbene ligands: Synthesis, structure and catalytic application over amide synthesis
}

\author{
MUTHUKUMARAN NIRMALA and PERIASAMY VISWANATHAMURTHI* \\ Department of Chemistry, Periyar University, Salem, Tamil Nadu 636 011, India \\ e-mail: viswanathamurthi72@gmail.com
}

MS received 18 April 2016; revised 12 august 2016; accepted 16 August 2016

\begin{abstract}
A series of four imidazolium salts was synthesized by the reaction of 2-bromopyridine with 1substituted imidazoles. These imidazolium salts (1a-d) were successfully employed as ligand precursors for the syntheses of new ruthenium(II) complexes bearing neutral bidentate ligands of N-heterocyclic carbene and pyridine donor moiety. The NHC-ruthenium(II) complexes (3a-d) were synthesized by reacting the appropriately substituted pyridine-functionalized $\mathrm{N}$-heterocyclic carbenes with $\mathrm{Ag}_{2} \mathrm{O}$ forming the $\mathrm{NHC}$-silver bromide in situ followed by transmetalation with $\left[\mathrm{RuHCl}(\mathrm{CO})\left(\mathrm{PPh}_{3}\right)_{3}\right]$. The new complexes were characterized by elemental analyses and spectroscopy (IR, UV-Vis, ${ }^{1} \mathrm{H},{ }^{13} \mathrm{C},{ }^{31} \mathrm{P}-\mathrm{NMR}$ ) as well as ESI mass spectrometry. Based on the spectral results, an octahedral geometry was assigned for all the complexes. The complexes were shown to be efficient catalysts for the one-pot conversion of various aldehydes to their corresponding primary amides with good to excellent isolated yields using $\mathrm{NH}_{2} \mathrm{OH} . \mathrm{HCl}$ and $\mathrm{NaHCO}_{3}$. The effects of solvent, base, temperature, time and catalyst loading were also investigated. A broad range of amides were successfully synthesized with excellent isolated yields using the above optimized protocol. Notably, the complex $\mathbf{3 a}$ was found to be a very efficient and versatile catalyst towards amidation of a wide range of aldehydes.
\end{abstract}

Keywords. Pyridine-functionalized carbene ligand; [Ru-NHC] complexes; transmetalation; aldehyde to amide conversion

\section{Introduction}

Since their discovery over two decades ago, $N$-heterocyclic carbenes (NHCs) have earned a prominent position in the toolbox of the organometallic chemist. ${ }^{1}$ Their high $\sigma$-donating ability and steric bulk have proven functional in stabilizing transition metal complexes which have found numerous applications in catalysis. ${ }^{2-10}$ More recently, a number of novel divalent carbon species have been synthesized that are based on other heterocycles ${ }^{11-21}$ offering new avenues to alter one or both of the $\sigma$ - and $\pi$-donor characteristics of the carbene. Many types of interesting NHC containing ligands have been designed to search for new efficient catalysts. ${ }^{22}$ In particular, functionalized NHC ligands and catalytic activities of their metal complexes have been the subject of intensive studies. ${ }^{23}$ Incorporation of a classical donor into NHC compounds offers vast opportunities in the design of the functionalized NHC ligands. ${ }^{23 a}$ The noncarbon donor atom would act as a hemilabile arm,

*For correspondence capable of reversible dissociation from the metal center. Among the ligands containing various classical donors, the hybrid NHC ligands containing nitrogen donors have attracted considerable interest, particularly the pyridine-functionalized bidentate NHC ligands which have been extensively studied. So far, metal complexes including group 9 (Rh, Ir), ${ }^{24,25} 10$ (Ni, Pd), ${ }^{26,27}$ and $11(\mathrm{Cu}, \mathrm{Ag})^{28,29}$ metal complexes of pyridinefunctionalized NHC ligands have been reported. They showed efficient catalytic activity towards hydrosilation of acetylenes, ${ }^{25 a}$ cyclization of acetylenic carboxylic acids, ${ }^{25 a}$ transfer hydrogenation of ketones, ${ }^{25 a}$ reduction of nitroarenes, ${ }^{25 \mathrm{~b}} \mathrm{C}-\mathrm{C}$ coupling reactions, ${ }^{27}$ and olefin polymerization. ${ }^{26 a, 27 b}$ It is of great interest to synthesise and characterize new transition metal complexes other than above metals with pyridine-functionalized NHCs and to study their applications in catalysis.

Amides are a very important class of compounds in chemistry as well as biology that have widely been utilized as intermediate in peptide and protein syntheses, intensifiers of perfume, drugs, fine chemicals, antiblock reagents, colour pigments for ink detergents and lubricants. ${ }^{30}$ Over the past few decades, a plethora of 
approaches for the formation of amide compounds have been explored and addressed. Among them, some innovative processes mainly include the direct synthesis of amides from thioesters ${ }^{31}$ or azides, ${ }^{32}$ amidation of alcohols with amines, ${ }^{33}$ and the generation of amides from bromo, nitro compounds with amines. ${ }^{34}$ Nevertheless, the majority of these developed approaches for amide synthesis are related to the intermediate utilization of carboxylic acids or activated carboxylic acid derivatives. These methods are low in atom efficiency, often involve potentially explosive molecules as catalysts and generate substantial waste ${ }^{35,36}$ making their environmental profile unfavourable. This is the compelling reason for identifying atom-economical, safe, and efficient amide bond formation as a key thrust area of green chemistry research. ${ }^{37}$ To address the problem, several transition-metal based catalysts have been developed. Of them, ruthenium complexes have been extensively studied due to their interesting structure ${ }^{38}$ and catalytic properties. ${ }^{39}$ The earlier reports indicated NHC-promoted Ru catalytic systems showed limited or no activity on the amidation of aldehydes. ${ }^{40}$ Later, Muthaiah et al., have reported ${ }^{41}$ some [Ru(II)$\mathrm{NHC}$ ] complexes generated from in situ reaction of $\mathrm{RuH}_{2}\left(\mathrm{PPh}_{3}\right)_{4}$ and an imidazole-based NHC precursors and used as efficient catalysts for amidation of aldehydes and alcohols. In their work, no catalytic activity is observed in the absence of a strong base such as $\mathrm{NaH}$ and the reaction required high amounts of $\mathrm{NaH}$, more than for generation of the NHC ligand. The usage of strong base such as $\mathrm{NaH}$ leads to the formation of various side products. Apart from that, storing and handling of strong bases such as $\mathrm{NaH}$ require special attention and care which make the reaction less convenient to be carried out. Significant efforts have been made in recent years for the development of one-pot process enabling direct formation of primary amides from aldehydes and hydroxylamine derivatives via rearrangement of the in situ formed aldoximes, which is an elegant alternative pathway. The rearrangement of aldoximes into amides has been reported using transition metal catalysts containing nickel, ${ }^{42}$ copper, ${ }^{43}$ ruthenium, ${ }^{44}$ palladium, ${ }^{45}$ iridium,${ }^{46}$ rhodium ${ }^{47}$ and zinc. $^{48}$

In contrast to the considerable growth of literature on the chemistry of $N$-heterocyclic carbenes, to the best of our knowledge, there are no reports available for catalytic transformation of aldehydes to amides by ruthenium(II) carbonyl complexes with the pyridinefunctionalized $N$-heterocyclic carbene ligands. Herein, we report a simple direct method of [Ru-NHC] catalyzed conversion of aromatic aldehydes into primary amides via aldoximes under neat conditions.

\section{Experimental}

\subsection{General comments}

All experiments were performed under an atmosphere of dry argon using standard Schlenk techniques and a vacuum-line system. Unless otherwise stated, reagents were used as received from commercial sources. Solvents were deoxygenated immediately prior to use. All $\mathrm{Ag}_{2} \mathrm{O}$ reactions were carried out under exclusion of light. Reactions were monitored by thin-layer chromatography using Merck 1.0555 aluminium sheets precoated with silica gel 60 F254, and the spots were examined with UV light at $254 \mathrm{~nm}$ or under iodine. Melting points were measured for samples in sealed capillaries on a Technico micro heating table apparatus and are uncorrected. Column chromatography purifications were performed using Merck silica gel 60 $(0.063-0.200 \mathrm{~mm})$.

\subsection{Spectroscopy}

IR spectra were recorded on a Nicolet Avatar model FTIR spectrophotometer (range $4000-400 \mathrm{~cm}^{-1}$ ) in $\mathrm{KBr}$ pellets. ${ }^{1} \mathrm{H},{ }^{13} \mathrm{C}$ and ${ }^{31} \mathrm{P}$ NMR spectra were recorded on Bruker AV400 spectrometer at $300 \mathrm{~K}$, using DMSO- $d_{6}$ or $\mathrm{CDCl}_{3}$. Chemical shifts ( $\delta$, parts per million) are quoted relative to tetramethylsilane or $o$-phosphoric acid (internal standards). ESI-Mass spectra were obtained in the ES+ (electron spray positive ionization) mode for all compounds using liquid chromatography mass spectrometry quadrupole time-of-flight Micro Analyzer (Shimadzu) at SAIF, Punjab University, Chandigarh.

\subsection{Elemental analyses}

Elemental analyses were performed using a Vario EL III elemental analyzer.

\subsection{Materials}

1-Substituted imidazoles ${ }^{49}$ and $\left[\mathrm{RuHCl}(\mathrm{CO})\left(\mathrm{PPh}_{3}\right)_{3}\right]^{50}$ were prepared according to the previously published procedures.

\subsection{Preparation of NHC ligands}

A solution of 2-bromopyridine (3.80 g, $24 \mathrm{mmol})$ and 1 -substituted imidazole $(24 \mathrm{mmol})$ was stirred neat at $160^{\circ} \mathrm{C}$ for $20 \mathrm{~h}$. After it was cooled, the mixture was dissolved in $\mathrm{CH}_{2} \mathrm{Cl}_{2}(20 \mathrm{~mL})$ and $\mathrm{Et}_{2} \mathrm{O}(100 \mathrm{~mL})$ was added. The precipitate was collected and redissolved in 
$\mathrm{CH}_{2} \mathrm{Cl}_{2}$, and precipitated with pentane to give pyridinefunctionalized imidazolium salt $(\mathbf{1 a}-\mathbf{d})$ as a pale yellow powder in good yield.

2.5a Compound 1a $(R=P h)$ : The synthetic procedure of this compound was same as that of the above representative procedure, using 1-phenyl imidazole to give a pale yellow solid 1a. Yield: $91 \%$; M.p. $79-82^{\circ} \mathrm{C}$; Anal. Calcd(\%) for $\mathrm{C}_{14} \mathrm{H}_{12} \mathrm{~N}_{3} \mathrm{Br}$ : C, 55.65; H, 4.00; $\mathrm{N}, 13.91$. Found(\%): C, 55.81; H, 4.33; N, 13.62; ${ }^{1} \mathrm{H}$ NMR (300.13 MHz, $\left.\mathrm{CDCl}_{3}\right): \delta 11.4(1 \mathrm{H}, \mathrm{s}, \mathrm{NCHN})$, $8.6(1 \mathrm{H}, \mathrm{d}, J=8.1 \mathrm{~Hz}, \mathrm{Py}-\mathrm{H}), 8.3(1 \mathrm{H}, \mathrm{m}, \mathrm{Py}-\mathrm{H}), 8.3$ $(1 \mathrm{H}, \mathrm{t}, \mathrm{imi}-\mathrm{H}), 8.0(1 \mathrm{H}, \mathrm{m}, \mathrm{Py}-\mathrm{H}), 7.9(1 \mathrm{H}, \mathrm{t}, \mathrm{imi}-\mathrm{H})$, 7.7-7.4 (5H, m, Ar-H), 7.4 (1H, m, Py-H); ${ }^{13} \mathrm{C}$ NMR $\left(75.47 \mathrm{MHz}, \mathrm{CDCl}_{3}\right): \delta 154.2(\mathrm{C}=\mathrm{N}), 149.1(\mathrm{NCHN})$, 130.4 (Ar-C), 129.4 (Ar-C), 127.9 (Ar-C), 125.9 (ArC), 123.6 (imi-C), 122.0 (Ar-C), 119.4 (imi-C), 117.2 (Ar-C), 115.3 (Ar-C), 114.6 (Ar-C); ESI: $m / z$ calcd. For $\mathrm{C}_{14} \mathrm{H}_{12} \mathrm{~N}_{3} \mathrm{Br}[\mathrm{M}-\mathrm{Br}]^{+}$, 222.23; Found, $[\mathrm{M}-\mathrm{Br}]^{+}$, 222.17 .

2.5b Compound $\mathbf{l b}\left(R={ }^{i} P r\right)$ : The synthetic procedure of this compound was the same as that of above representative procedure, using 1-isopropyl imidazole to give a pale yellow solid 1b. Yield: 89\%; M.p. 64$66^{\circ} \mathrm{C}$; Anal. Calcd(\%) for $\mathrm{C}_{11} \mathrm{H}_{14} \mathrm{~N}_{3} \mathrm{Br}$ : C, 49.27; $\mathrm{H}$, 5.26; N, 15.67. Found(\%): C, 49.44; H, 5.37; N, 15.83; ${ }^{1} \mathrm{H}$ NMR $\left(300.13 \mathrm{MHz}, \mathrm{CDCl}_{3}\right): \delta 10.8(1 \mathrm{H}, \mathrm{s}, \mathrm{NCHN})$, $8.5(1 \mathrm{H}, \mathrm{d}, J=8.2 \mathrm{~Hz}, \mathrm{Py}-\mathrm{H}), 8.3(1 \mathrm{H}, \mathrm{m}, \mathrm{Py}-\mathrm{H}), 8.2$ $(1 \mathrm{H}, \mathrm{t}, \mathrm{imi}-\mathrm{H}), 8.0(1 \mathrm{H}, \mathrm{m}, \mathrm{Py}-\mathrm{H}), 7.9(1 \mathrm{H}, \mathrm{t}, \mathrm{imi}-$ $\mathrm{H}), 7.6(1 \mathrm{H}, \mathrm{m}, \mathrm{Py}-\mathrm{H}), 4.8\left(1 \mathrm{H}, \mathrm{m}, \mathrm{CH}\left(\mathrm{CH}_{3}\right)_{2}\right), 1.6$ $\left(6 \mathrm{H}, \mathrm{m}, \mathrm{CH}\left(\mathrm{CH}_{3}\right)_{2}\right) ;{ }^{13} \mathrm{C} \mathrm{NMR}\left(75.47 \mathrm{MHz}, \mathrm{CDCl}_{3}\right)$ : $\delta 153.4(\mathrm{C}=\mathrm{N}), 148.2(\mathrm{NCHN}), 129.9(\mathrm{Ar}-\mathrm{C}), 127.5$ (Ar-C), 124.5 (imi-C), 122.3 (imi-C), 121.4 (Ar-C), 119.4 (Ar-C), $30.2\left(\mathrm{CH}_{3}\right), 29.3\left(\mathrm{CH}_{3}\right)$; ESI: $\mathrm{m} / z$ calcd. For $\mathrm{C}_{11} \mathrm{H}_{14} \mathrm{~N}_{3} \mathrm{Br}[\mathrm{M}-\mathrm{Br}]^{+}$, 188.25; Found, $[\mathrm{M}-\mathrm{Br}]^{+}$, 188.17.

2.5c Compound $1 c\left(R={ }^{t} B u\right)$ : The synthetic procedure of this compound was the same as that of above representative procedure, using 1-tert-butyl imidazole to give a pale yellow solid 1c. Yield: 91\%; M.p. 68-70 ${ }^{\circ} \mathrm{C}$; Anal. Calcd $(\%)$ for $\mathrm{C}_{12} \mathrm{H}_{16} \mathrm{~N}_{3} \mathrm{Br}$ : C, 51.08; $\mathrm{H}, 5.72 ; \mathrm{N}, 14.89$. Found(\%): C, 51.39; H, 5.83; N, 14.62; ${ }^{1} \mathrm{H}$ NMR $\left(300.13 \mathrm{MHz}, \mathrm{CDCl}_{3}\right): \delta 11.7(1 \mathrm{H}, \mathrm{s}$, NCHN $), 8.6(1 \mathrm{H}, \mathrm{d}, J=8.0 \mathrm{~Hz}, \mathrm{Py}-\mathrm{H}), 8.5(1 \mathrm{H}, \mathrm{dd}$, $J=4.8 \mathrm{~Hz}, J=1.0 \mathrm{~Hz}, \mathrm{Py}-\mathrm{H}), 8.3(1 \mathrm{H}, \mathrm{t}, \mathrm{imi}-\mathrm{H}), 8.1$ $(1 \mathrm{H}, \mathrm{m}, \mathrm{Py}-\mathrm{H}), 7.6(1 \mathrm{H}, \mathrm{t}, \mathrm{imi}-\mathrm{H}), 7.3(1 \mathrm{H}, \mathrm{dd}, J=7.1$ $\mathrm{Hz}, J=4.8 \mathrm{~Hz}, \mathrm{Py}-\mathrm{H}), 4.6\left(2 \mathrm{H}, \mathrm{t},{ }^{t} \mathrm{Bu}\right), 1.9(2 \mathrm{H}, \mathrm{m}$, $\left.{ }^{t} \mathrm{Bu}\right), 1.3\left(2 \mathrm{H}, \mathrm{m},{ }^{t} \mathrm{Bu}\right), 0.9\left(3 \mathrm{H}, \mathrm{m},{ }^{t} \mathrm{Bu}\right) ;{ }^{13} \mathrm{C} \mathrm{NMR}$ $\left(75.47 \mathrm{MHz}, \mathrm{CDCl}_{3}\right): \delta 153.2(\mathrm{C}=\mathrm{N}), 149.5(\mathrm{NCHN})$, 141.2 (Ar-C), 136.9 (Ar-C), 129.4 (Ar-C), 127.3 (imiC), 121.1 (imi-C), $115.0(\mathrm{Ar}-\mathrm{C}), 50.0\left(\mathrm{C},{ }^{t} \mathrm{Bu}\right), 39.3$
$\left(\mathrm{C},{ }^{t} \mathrm{Bu}\right), 19.4\left(\mathrm{C},{ }^{t} \mathrm{Bu}\right), 14.2\left(\mathrm{C},{ }^{t} \mathrm{Bu}\right)$; ESI: $m / z$ calcd. For $\mathrm{C}_{12} \mathrm{H}_{16} \mathrm{~N}_{3} \mathrm{Br}[\mathrm{M}-\mathrm{Br}]^{+}, 202.28$; Found, $[\mathrm{M}-\mathrm{Br}]^{+}$, 202.08 .

2.5d Compound $1 \mathrm{~d}(R=$ Mes): The synthetic procedure of this compound was the same as that of above representative procedure, using 1-mesityl imidazole to give a pale yellow solid 1d. Yield: $91 \%$; M.p. $72-75^{\circ} \mathrm{C}$; Anal. Calcd(\%) for $\mathrm{C}_{17} \mathrm{H}_{18} \mathrm{~N}_{3} \mathrm{Br}$ : C, 59.31; H, 5.27; N, 12.21. Found(\%): C, 59.07; H, 5.41; N, 12.39; ${ }^{1} \mathrm{H}$ NMR (300.13 MHz, $\left.\mathrm{CDCl}_{3}\right): \delta 11.2(1 \mathrm{H}, \mathrm{s}, \mathrm{NCHN})$, $8.6(1 \mathrm{H}, \mathrm{d}, J=8.0 \mathrm{~Hz}, \mathrm{Py}-\mathrm{H}), 8.3(1 \mathrm{H}, \mathrm{m}, \mathrm{Py}-\mathrm{H})$, $8.2(1 \mathrm{H}, \mathrm{t}, \mathrm{imi}-\mathrm{H}), 8.1(1 \mathrm{H}, \mathrm{m}, \mathrm{Py}-\mathrm{H}), 7.9(1 \mathrm{H}, \mathrm{t}, \mathrm{imi}-$ $\mathrm{H}), 7.7(1 \mathrm{H}, \mathrm{m}, \mathrm{Py}-\mathrm{H}), 2.4\left(3 \mathrm{H}, \mathrm{s}, \mathrm{CH}_{3}\right), 2.2(6 \mathrm{H}, \mathrm{s}$, $\left.\mathrm{CH}_{3}\right) ;{ }^{13} \mathrm{C}$ NMR $\left(75.47 \mathrm{MHz}, \mathrm{CDCl}_{3}\right): \delta 152.4(\mathrm{C}=\mathrm{N})$, 149.4 (NCHN), 129.3 (Ar-C), 126.7 (Ar-C), 123.2 (imi-C), 120.1 (imi-C), 119.5 (Ar-C), 117.4 (Ar-C), $30.2\left(\mathrm{CH}_{3}\right), 28.5\left(\mathrm{CH}_{3}\right), 28.2\left(\mathrm{CH}_{3}\right)$; ESI: $m / z$ calcd. For $\mathrm{C}_{17} \mathrm{H}_{18} \mathrm{~N}_{3} \mathrm{Br}[\mathrm{M}-\mathrm{Br}]^{+}$, 264.35; Found, [M-Br] ${ }^{+}$, 264.17.

\subsection{Syntheses of Pyridine-functionalized N-heterocyclic carbene ruthenium(II) complexes (3a-d)}

Pyridine-functionalized imidazolium salts $(\mathrm{R}=\mathrm{Ph}(\mathbf{1 a})$, $i \operatorname{Pr}(\mathbf{1 b}), t \mathrm{Bu}(\mathbf{1 c})$, Mes (1d) $(2 \mathrm{mmol})$ and Silver(I) oxide $(0.231 \mathrm{~g}, 1 \mathrm{mmol})$ in $25 \mathrm{~mL}$ of dichloromethane were stirred in dark at room temperature for $24 \mathrm{~h}$. The unreacted $\mathrm{Ag}_{2} \mathrm{O}$ was removed by filtration over a pad of Celite. The resulting yellowish solution was concentrated to $2 \mathrm{~mL}$ then $\mathrm{Et}_{2} \mathrm{O}$ was added to precipitate the product as a white, flaky solid. The solid was isolated, washed with $\mathrm{Et}_{2} \mathrm{O}(3 \times 5 \mathrm{~mL})$, and dried under reduced pressure to yield the corresponding Ag-NHC complexes as an off-white solid. To the dichloromethane solution $(15 \mathrm{~mL})$ of $\mathrm{Ag}-\mathrm{NHC}$ complex, $\left[\mathrm{RuHCl}(\mathrm{CO})\left(\mathrm{PPh}_{3}\right)_{3}\right](0.9524 \mathrm{~g}, 1 \mathrm{mmol})$ was added, and the mixture was stirred overnight in dark at room temperature. After filtration through a Celite plug to remove the $\mathrm{AgBr}$ by-product, the solvent was reduced to $5 \mathrm{~mL}$, and diethyl ether $(20 \mathrm{~mL})$ was added to precipitate the crude product. The resulting crude product was purified using column chromatography ( $\mathrm{SiO}_{2}, 10: 1 \mathrm{CH}_{2} \mathrm{Cl}_{2}$ /acetone).

2.6a Compound $\mathbf{3 a}(R=P h)$ : The synthetic procedure of this compound was the same as that of above representative procedure, using $\mathbf{1 a}$ to give a yellow solid 3a. Yield: $76 \%$; M.p. $231-234^{\circ} \mathrm{C}$; Anal. Calcd $(\%)$ for $\mathrm{C}_{33} \mathrm{H}_{27} \mathrm{~N}_{3} \mathrm{OClPRu}$ : C, 61.06; $\mathrm{H}, 4.19 ; \mathrm{N}, 6.47$. Found(\%): C, 61.39; H, 4.42; N, 6.12; IR (KBr disks, $\left.\mathrm{cm}^{-1}\right) ; 1974(\mathrm{C} \equiv \mathrm{O}), 1560(\mathrm{C}=\mathrm{C}), 1547(\mathrm{~N}-\mathrm{C}-\mathrm{N})$, $1502(\mathrm{C}-\mathrm{C}), 1580(\mathrm{C}=\mathrm{N}) ;{ }^{1} \mathrm{H}$ NMR $(300.13 \mathrm{MHz}$, 
$\left.\mathrm{CDCl}_{3}\right): \delta 8.8-7.6(4 \mathrm{H}, \mathrm{m}, \mathrm{Py}-\mathrm{H}), 6.9-6.5(5 \mathrm{H}, \mathrm{m}$, Ar-H), 6.4-6.3 (15H, m, $\left.\mathrm{PPh}_{3}\right),-4.5(1 \mathrm{H}, \mathrm{s}, \mathrm{Ru}-\mathrm{H})$; ${ }^{13} \mathrm{C}$ NMR $\left(75.47 \mathrm{MHz}, \mathrm{CDCl}_{3}\right): \delta 200.9(\mathrm{C} \equiv \mathrm{O}), 198.6$ $\left(\mathrm{Ru}-\mathrm{C}_{\text {carbene }}\right), 152.7(\mathrm{C}=\mathrm{N}), 137.2(\mathrm{Ar}-\mathrm{C}), 134.9(\mathrm{Ar}-$ C), 128.5 (Ar-C), 125.8 (Ar-C), 124.4 (Ar-C), 123.8 (Ar-C), $120.1(\mathrm{Ar}-\mathrm{C}), 115.1(\mathrm{Ar}-\mathrm{C}), 112.5(\mathrm{Ar}-\mathrm{C}) ;{ }^{31} \mathrm{P}$ NMR (162 MHz, $\mathrm{CDCl}_{3}$ ), $\delta 29.9$ (s); ESI: $m / z$ calcd. For $\mathrm{C}_{33} \mathrm{H}_{27} \mathrm{~N}_{3} \mathrm{OClPRu}[\mathrm{M}]^{+}$, 649.08; Found, $[\mathrm{M}]^{+}$, 649.07.

2.6b Compound $3 \boldsymbol{b}\left(R={ }^{i} \mathrm{Pr}\right)$ : The synthetic procedure of this compound was the same as that of above representative procedure, using $\mathbf{1 b}$ to give a yellow solid 3b. Yield: $81 \%$; M.p. $212-216^{\circ} \mathrm{C}$; Anal. Calcd(\%) for $\mathrm{C}_{30} \mathrm{H}_{29} \mathrm{~N}_{3} \mathrm{OClPRu}$ : C, 58.58; H, 4.75; N, 6.83. Found(\%): C, 58.81; H, 4.92; N, 6.51; IR (KBr disks, $\left.\mathrm{cm}^{-1}\right) ; 1981(\mathrm{C} \equiv \mathrm{O}), 1564(\mathrm{C}=\mathrm{C}), 1552(\mathrm{~N}-\mathrm{C}-\mathrm{N})$, $1510(\mathrm{C}-\mathrm{C}), 1586(\mathrm{C}=\mathrm{N})$; ${ }^{1} \mathrm{H}$ NMR $(300.13 \mathrm{MHz}$, $\left.\mathrm{CDCl}_{3}\right): \delta 8.7-7.8(4 \mathrm{H}, \mathrm{m}, \mathrm{Py}-\mathrm{H}), 6.8-6.2(15 \mathrm{H}, \mathrm{m}$, $\left.\mathrm{PPh}_{3}\right), 4.7\left(1 \mathrm{H}, \mathrm{m}, \mathrm{CH}\left(\mathrm{CH}_{3}\right)_{2}\right), 1.7\left(6 \mathrm{H}, \mathrm{m}, \mathrm{CH}\left(\mathrm{CH}_{3}\right)_{2}\right)$ $-4.54(1 \mathrm{H}, \mathrm{s}, \mathrm{Ru}-\mathrm{H}) ;{ }^{13} \mathrm{C} \mathrm{NMR}\left(75.47 \mathrm{MHz}, \mathrm{CDCl}_{3}\right): \delta$ $202.4(\mathrm{C} \equiv \mathrm{O}), 197.4$ (Ru-C $\left.\mathrm{C}_{\text {carbene }}\right), 154.7(\mathrm{C}=\mathrm{N}), 138.1$ (Ar-C), 135.7 (Ar-C), 129.2 (Ar-C), 127.3 (Ar-C), 125.7 (Ar-C), $123.6(\mathrm{Ar}-\mathrm{C}), 122.8(\mathrm{Ar}-\mathrm{C}), 119.1(\mathrm{Ar}-$ C), $118.2(\mathrm{Ar}-\mathrm{C}), 116.4(\mathrm{Ar}-\mathrm{C}), 107.7(\mathrm{Ar}-\mathrm{C}), 31.3$ $\left(\mathrm{CH}_{3}\right), 29.4\left(\mathrm{CH}_{3}\right) ;{ }^{31} \mathrm{P}$ NMR $\left(162 \mathrm{MHz}, \mathrm{CDCl}_{3}\right): \delta$ 29.9 (s); ESI: $m / z$ calcd. For $\mathrm{C}_{30} \mathrm{H}_{29} \mathrm{~N}_{3} \mathrm{OClPRu}[\mathrm{M}]^{+}$, 615.07; Found, $[\mathrm{M}]^{+}, 615.65$.

2.6c Compound $3 c\left(R={ }^{t} \mathrm{Bu}\right)$ : The synthetic procedure of this compound was the same as that of above representative procedure, using 1c to give a yellow solid 3c. Yield: 78\%; M.p. 209-211 ${ }^{\circ} \mathrm{C}$; Anal. Calcd(\%) for $\mathrm{C}_{31} \mathrm{H}_{31} \mathrm{~N}_{3} \mathrm{OClPRu}$ : C, 59.19; $\mathrm{H}, 4.97 ; \mathrm{N}, 6.68$. Found(\%): C, 59.42; H, 4.63; N, 6.89; IR (KBr disks, $\left.\mathrm{cm}^{-1}\right) ; 1979(\mathrm{C} \equiv \mathrm{O}), 1572(\mathrm{C}=\mathrm{C}), 1549(\mathrm{~N}-\mathrm{C}-\mathrm{N})$, $1504(\mathrm{C}-\mathrm{C}), 1574(\mathrm{C}=\mathrm{N}) ;{ }^{1} \mathrm{H}$ NMR $(300.13 \mathrm{MHz}$, $\left.\mathrm{CDCl}_{3}\right): \delta 8.9-7.6(4 \mathrm{H}, \mathrm{m}, \mathrm{Py}-\mathrm{H}), 6.7-6.4(15 \mathrm{H}, \mathrm{m}$, $\left.\mathrm{PPh}_{3}\right), 1.7\left(2 \mathrm{H}, \mathrm{m},{ }^{t} \mathrm{Bu}\right), 1.7\left(2 \mathrm{H}, \mathrm{m},{ }^{t} \mathrm{Bu}\right), 1.2(2 \mathrm{H}$, $\left.\mathrm{m},{ }^{t} \mathrm{Bu}\right), 0.9\left(3 \mathrm{H}, \mathrm{m},{ }^{t} \mathrm{Bu}\right),-4.4(1 \mathrm{H}, \mathrm{s}, \mathrm{Ru}-\mathrm{H}) ;{ }^{13} \mathrm{C}$ NMR (75.47 MHz, $\left.\mathrm{CDCl}_{3}\right): \delta 203.6(\mathrm{C} \equiv \mathrm{O}), 195.3$ $\left(\mathrm{Ru}-\mathrm{C}_{\text {carbene }}\right), 154.7(\mathrm{C}=\mathrm{N}), 137.9(\mathrm{Ar}-\mathrm{C}), 136.4(\mathrm{Ar}-$ C), 133.1 (Ar-C), 129.3 (Ar-C), 128.7 (Ar-C), 127.2 (Ar-C), 126.7 (Ar-C), 124.3 (Ar-C), 123.4 (Ar-C), 122.9 (Ar-C), $108.4(\mathrm{Ar}-\mathrm{C}), 51.3\left(\mathrm{C},{ }^{t} \mathrm{Bu}\right), 38.3(\mathrm{C}$, $\left.{ }^{t} \mathrm{Bu}\right), 18.4\left(\mathrm{C},{ }^{t} \mathrm{Bu}\right), 16.2\left(\mathrm{C},{ }^{t} \mathrm{Bu}\right)$; ESI: $m / z$ calcd. For $\mathrm{C}_{31} \mathrm{H}_{31} \mathrm{~N}_{3} \mathrm{OClPRu}[\mathrm{M}]^{+}$, 629.09; Found, [M] ${ }^{+}, 629.05$.

2.6d Compound $3 \boldsymbol{d}(R=M e s)$ : The synthetic procedure of this compound was the same as that of above representative procedure, using $\mathbf{1 d}$ to give a yellow solid 3d. Yield: 82\%; M.p. $230-234^{\circ} \mathrm{C}$; Anal. Calcd(\%) for $\mathrm{C}_{36} \mathrm{H}_{31} \mathrm{~N}_{3}$ OClPRu: C, 62.56; $\mathrm{H}, 4.81 ; \mathrm{N}, 6.08$. Found(\%): C, 62.83; H, 4.57; N, 6.43; IR (KBr disks, $\left.\mathrm{cm}^{-1}\right) ; 1984(\mathrm{C} \equiv \mathrm{O}), 1576(\mathrm{C}=\mathrm{C}), 1543(\mathrm{~N}-\mathrm{C}-\mathrm{N})$, $1512(\mathrm{C}-\mathrm{C}), 1581(\mathrm{C}=\mathrm{N}) ;{ }^{1} \mathrm{H}$ NMR $(300.13 \mathrm{MHz}$, $\left.\mathrm{CDCl}_{3}\right): \delta 7.7-7.4(4 \mathrm{H}, \mathrm{m}, \mathrm{Py}-\mathrm{H}), 6.8-6.4(15 \mathrm{H}, \mathrm{m}$, $\left.\mathrm{PPh}_{3}\right), 3.4\left(3 \mathrm{H}, \mathrm{s}, \mathrm{CH}_{3}\right), 2.7\left(3 \mathrm{H}, \mathrm{s}, \mathrm{CH}_{3}\right), 2.1(3 \mathrm{H}$, s, $\left.\mathrm{CH}_{3}\right),-4.78(1 \mathrm{H}, \mathrm{s}, \mathrm{Ru}-\mathrm{H}) ;{ }^{13} \mathrm{C}$ NMR $(75.47 \mathrm{MHz}$, $\left.\mathrm{CDCl}_{3}\right): \delta 204.1(\mathrm{C} \equiv \mathrm{O}), 195.2\left(\mathrm{Ru}-\mathrm{C}_{\text {carbene }}\right), 147.1$ $(\mathrm{C}=\mathrm{N}), 131.5(\mathrm{Ar}-\mathrm{C}), 130.1(\mathrm{Ar}-\mathrm{C}), 128.6(\mathrm{Ar}-\mathrm{C})$, 127.3 (Ar-C), 126.5 (Ar-C), 123.2 (Ar-C), 108.9 (Ar-C), $35.1\left(\mathrm{CH}_{3}\right), 33.9\left(\mathrm{CH}_{3}\right), 25.7\left(\mathrm{CH}_{3}\right)$; ESI: $m / z$ calcd. For $\mathrm{C}_{36} \mathrm{H}_{33} \mathrm{~N}_{3} \mathrm{OClPRu}[\mathrm{M}]^{+}, 691.16$; Found, $[\mathrm{M}]^{+}, 691.46$.

\subsection{Representative procedure for ruthenium-catalyzed aldehydes to amides conversion}

The reaction vessel was charged with aldehyde (1 $\mathrm{mmol}), \mathrm{NH}_{2} \mathrm{OH} \cdot \mathrm{HCl}(1 \mathrm{mmol}), \mathrm{NaHCO}_{3}(1 \mathrm{mmol})$, [Ru-NHC] catalyst $(0.5 \mathrm{~mol} \%)$ and the mixture was placed under an atmosphere of $\mathrm{N}_{2}$. About $2 \mathrm{~mL}$ of dry and degassed toluene was added and the mixture was stirred for $15 \mathrm{~min}$ at room temperature followed by reflux for $8 \mathrm{~h}$. On completion of the reaction, 2-3 mL methanol was added to the mixture followed by filtration through Celite to remove the catalyst and $\mathrm{NaHCO}_{3}$. The crude product was then purified by column chromatography ( $\left.\mathrm{MeOH} / \mathrm{CH}_{2} \mathrm{Cl}_{2}, 1: 1\right)$ using silica (200400 mesh) as solid phase provided the amide in good yield. The resultant amide solution was subjected to GC analysis and the product was identified in comparison with authentic samples

\section{Results and Discussion}

\subsection{Synthesis and characterization of}

pyridine-functionalized $N$-heterocyclic carbene ligands

Pyridine-functionalized imidazolium salts (1a-d) were synthesized according to known literature procedure ${ }^{51}$ (Scheme 1) by the reaction of 2-bromopyridine with 1substituted imidazole stirred at $160^{\circ} \mathrm{C}$ for $20 \mathrm{~h}$. The new ligands (1a-d) obtained are highly air and moisture stable. The ligands were fully characterized by ${ }^{1} \mathrm{H}$ and ${ }^{13} \mathrm{C}$ NMR, mass spectra and elemental analysis.

\subsection{Synthesis of Precatalysts}

The synthetic plan to achieve the new ruthenium complexes disclosed herein was initially attempted via the 


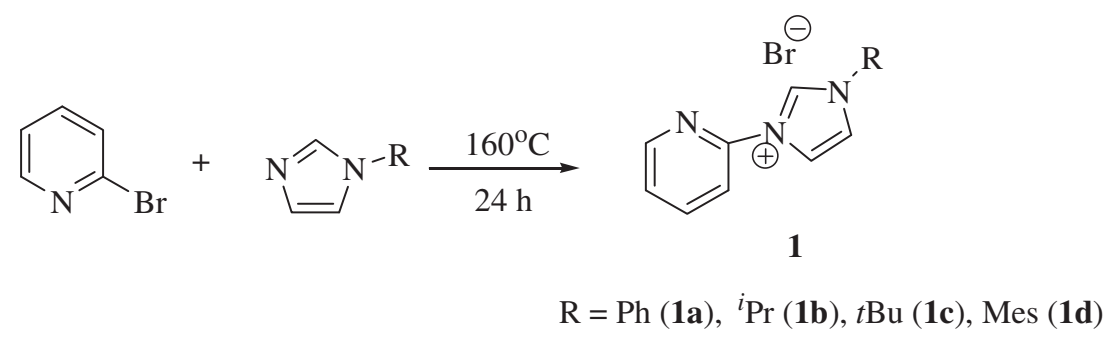

Scheme 1. General preparation of pyridine-functionalized imidazolium salts (1a-1d).

free carbene route. Imidazolium deprotonation using a strong base such as $t-\mathrm{BuOK}$ or $n-\mathrm{BuLi}$ and subsequent ruthenium coordination yielded the desired products in low yield with significant amounts of unidentified impurities. Hence, the mild silver base $\left(\mathrm{Ag}_{2} \mathrm{O}\right)$ has been used for the deprotonation in the syntheses of $\mathrm{N}$-heterocyclic carbene complexes. This procedure is probably one of the most general methods, because it generates an air-stable intermediate under mild reaction conditions, thus allowing a straightforward access to a wide range of transition metal complexes. It is often used successfully when other methods failed. The use of Ag-NHC complexes as carbene transfer reagents provide a convenient way to overcome the difficulties arising from using strong bases, inert atmospheres, and complicated workups. All the desired [Ru-NHC] complexes (3a-d) were synthesized following the carbene transfer route, more precisely transmetalation of the in situ generated NHC-silver(I) bromide complexes with the $\left[\mathrm{RuHCl}(\mathrm{CO})\left(\mathrm{PPh}_{3}\right)_{3}\right]$ precursor (Scheme 2). All the complexes (3a-d) are highly soluble in $\mathrm{CH}_{2} \mathrm{Cl}_{2}, \mathrm{CHCl}_{3}$, THF and DMSO but insoluble in diethyl ether and hydrocarbon solvents. They were fully characterized by spectral $\left({ }^{1} \mathrm{H}\right.$ NMR, ${ }^{13} \mathrm{C}$ NMR, IR, mass $)$ and elemental analysis studies.

\subsection{Spectroscopic description}

IR spectra of free ligand were compared with new complexes in order to confirm the coordination of ligand to ruthenium metal. The new $[\mathrm{Ru}-\mathrm{NHC}]$ complexes $(\mathbf{3 a}-$ d) show a $v$ CO stretch in the IR spectrum at $\sim 1981$ $\mathrm{cm}^{-1}$. The complexes showed a strong band in the region $1552-1543 \mathrm{~cm}^{-1}$ due to $v(\mathrm{~N}-\mathrm{C}-\mathrm{N})$. A strong vibration was observed at $1576-1560 \mathrm{~cm}^{-1}$ in the spectra of complexes corresponding to $\mathrm{C}=\mathrm{C}$ stretching. In all the ruthenium complexes, the band due to terminal $v(\mathrm{C}=\mathrm{N})$ group appeared at $1586-1581 \mathrm{~cm}^{-1}$. In addition to the above vibrations, the characteristic bands due to triphenylphosphine group were also present in the expected region. ${ }^{52}$

The generation of free carbene and subsequent formation of the $[\mathrm{Ru}-\mathrm{NHC}]$ complexes were unambiguously confirmed by the absence of the ${ }^{1} \mathrm{H}$ NMR resonances of imidazolium (NCHN) proton. The imidazolium ring backbone signals appeared around 8.2$7.6 \mathrm{ppm}$, the pyridine protons appeared in the region of $8.9-7.4 \mathrm{ppm}$. A signal at high field $(\sim-4.8 \mathrm{ppm})$ indicated the presence of the hydride ligand. Furthermore, the spectra of all the complexes showed a series of signals for aromatic protons at 7.4-6.4 ppm. In addition, a singlet appeared around 3.4-2.2 ppm for complexes 3a and 3d corresponding to terminal $\mathrm{CH}_{3}$ group protons. The spectra of the complexes showed a singlet at $1.7-0.9 \mathrm{ppm}$, which has been assigned to $t \mathrm{Bu}$ protons (Figures S1-S4, in Supplementary Information).

${ }^{13} \mathrm{C}$ NMR chemical shifts, which provide a useful diagnostic tool for metal carbene complexes, display the expected resonances with a single $\mathrm{Ru}-\mathrm{C}_{\text {carbene }}$ resonance at $c a$. $198.5-195.2 \mathrm{ppm}^{52}$ and the $\mathrm{C} \equiv \mathrm{O}$ signal<smiles>Brc1cn(I)cc1-c1ccccn1</smiles>

1

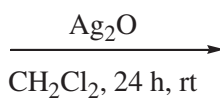

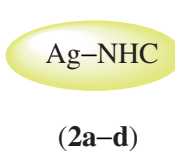

$(\mathbf{2 a}-\mathbf{d})$

$\mathrm{R}=\operatorname{Ph}(\mathbf{1 a}),{ }^{i} \operatorname{Pr}(\mathbf{1 b}), t \operatorname{Bu}(\mathbf{1 c}), \operatorname{Mes}(\mathbf{1 d})$

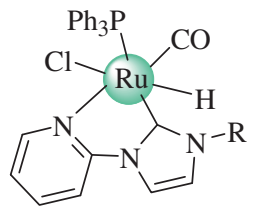

3

$\mathrm{R}=\mathrm{Ph}(\mathbf{3 a}),{ }^{i} \operatorname{Pr}(\mathbf{3 b}), t \mathrm{Bu}(\mathbf{3 c}), \operatorname{Mes}(\mathbf{3 d})$

Scheme 2. General synthesis of $[\mathrm{Ru}-\mathrm{NHC}]$ complexes (3a-3d). 
resonating at $\delta 204.1-200.9 \mathrm{ppm}$. In complexes (3a-d), aromatic carbon atoms observed around 136.4-108.3 $\mathrm{ppm}$. The presence of a peak at 154.2-147.1 ppm region was assigned to $\mathrm{C}=\mathrm{N}$ group. The presence of chemical shifts in the range of 33.9-25.7 ppm belonged to the methyl protons (Figures S5-S8, in Supplementary Information).

${ }^{31} \mathrm{P}$ NMR spectra were recorded for the complexes in order to confirm the presence of triphenylphosphine group. The complexes $\mathbf{3 a}$ and $\mathbf{3 b}$ exhibited only one signal at 29.9 and $29.9 \mathrm{ppm}$, consistent with the presence of only one triphenylphosphine ligand (Figures S9 and S10, in Supplementary Information).

The molecular ion peaks $\left(\mathbf{M}^{+}\right)$observed with $\mathrm{m} / \mathrm{z}$ values $222.17,188.17,202.08,264.17,649.07,615.65$ and 629.05 corresponding to the ligands $\mathbf{1 a - d}$ and $[\mathrm{Ru}-$ NHC] complexes 3a, 3b, 3c and 3d, respectively, in the ESI-MS spectra of the ligands and complexes, support the proposed molecular formulae (Figures S11S18, ESI). Unfortunately, we have not yet obtained high-quality crystals of Ru-NHC complexes suitable for X-ray single-crystal diffraction, suggesting that subtle structural factors are critical to stabilizing this species.

\subsection{Catalytic studies}

3.4a Catalytic aldehyde to amide conversion: The synthesized [Ru-NHC] complexes $\mathbf{3 a - d}$ were employed as catalysts for the conversion of aldehydes to their corresponding amides. In order to optimize the reaction conditions, the effect of solvents was tested and the results are summarized in Table 1. For the initial experiments, benzaldehyde was selected as a test-substrate and allowed to react in different solvents with catalytic quantities of [Ru-NHC] complex 3a in the presence of $\mathrm{NaHCO}_{3}$ additive. Benzene, DMF, DMSO, Toluene, THF, Xylene, $\mathrm{CHCl}_{3}, \mathrm{CH}_{3} \mathrm{CN}$ and $\mathrm{CH}_{2} \mathrm{Cl}_{2}$ are taken for our solvent variant study. Out of different solvents tested during the course of optimization, the solvents such as benzene, DMF, DMSO, Xylene, $\mathrm{CH}_{2} \mathrm{Cl}_{2}$ and $\mathrm{CHCl}_{3}$ could bring about only a little conversion (Table 1, Entries 1, 5, 6, 7, 10, 11). THF was found to be ineffective. However, acetonitrile gives a good yield of 84 and $89 \%$. When the reaction was carried out in toluene, 98 and $99 \%$ isolated product yield at the temperature of $110^{\circ} \mathrm{C}$ (Table 1, Entries 3, 4) was observed. It is interesting to note that toluene could not afford any conversion at $90^{\circ} \mathrm{C}$, hence implicating a crucial temperature effect on the reaction. A $20^{\circ} \mathrm{C}$ rise in temperature caused a spectacular effect on the reaction.

The choice of base was made, as the next step for optimization. No conversion was observed in the absence of base (Table 2). It has been observed that in toluene solvent, $\mathrm{NaHCO}_{3}$ and $\mathrm{KHCO}_{3}$ gave excellent isolated yields of 98 and 93\%, respectively (Table 2, Entry 4, 6) when compared to a much weaker base like $\mathrm{CH}_{3} \mathrm{COONa}$ and $\mathrm{Et}_{3} \mathrm{~N}$ (Table 2, Entry 9, 10). Thus it was concluded that $\mathrm{NaHCO}_{3}$ as a base in toluene solvent at $110^{\circ} \mathrm{C}$ is the optimized condition for this conversion.

Table 1. Effect of solvents on amidation of benzaldehyde to benzamide catalyzed by $[\mathrm{Ru}-\mathrm{NHC}]$ complex $\mathbf{3} \mathbf{a}^{a}$.

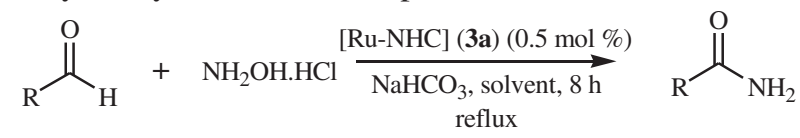

\begin{tabular}{lcccc}
\hline Entry & Solvent & Temp $\left({ }^{\circ} \mathrm{C}\right)$ & Time $(\mathrm{h})$ & $(\%)$ conversion $^{b}$ \\
\hline 1 & Benzene & 80 & 12 & 32 \\
2 & THF & 66 & 12 & n.r \\
3 & Toluene & 90 & 12 & n.r \\
$\mathbf{3}$ & Toluene & $\mathbf{1 1 0}$ & $\mathbf{8}$ & $\mathbf{9 8}$ \\
$\mathbf{4}$ & Toluene & $\mathbf{1 1 0}$ & $\mathbf{1 2}$ & $\mathbf{9 9}$ \\
5 & DMF & 153 & 12 & 27 \\
6 & DMSO & 189 & 12 & 42 \\
7 & Xylene & 144 & 12 & 37 \\
$\mathbf{8}$ & Acetonitrile & $\mathbf{8 2}$ & $\mathbf{8}$ & $\mathbf{8 4}$ \\
$\mathbf{9}$ & Acetonitrile & $\mathbf{8 2}$ & $\mathbf{1 2}$ & $\mathbf{8 9}$ \\
10 & Dichloromethane & 40 & 12 & 47 \\
11 & Chloroform & 61 & 12 & 31 \\
\hline
\end{tabular}

${ }^{a}$ Reaction Conditions: aldehyde $(1 \mathrm{mmol}), \mathrm{NH}_{2} \mathrm{OH} \cdot \mathrm{HCl}(1 \mathrm{mmol})$, $\mathrm{NaHCO}_{3}(1 \mathrm{mmol}),[\mathrm{Ru}-\mathrm{NHC}]$ catalyst $3 \mathrm{a}(0.5 \mathrm{~mol} \%)$ under $\mathrm{N}_{2}$, reflux for 8-12 $\mathrm{h} ;{ }^{b}$ Conversion determined by GC. 
Table 2. Effect of base on amidation of benzaldehyde to benzamide catalyzed by [Ru-NHC] complex $\mathbf{3} \mathbf{a}^{a}$.

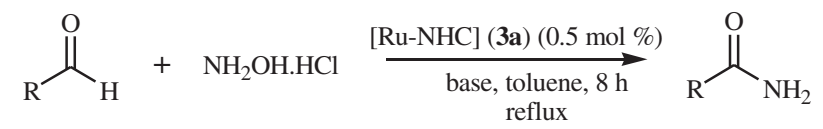

\begin{tabular}{lcc}
\hline Entry & Base & $(\%)$ conversion $^{b}$ \\
\hline 1 & $\mathrm{NaOH}_{2}$ & 48 \\
2 & $\mathrm{~K}_{2} \mathrm{CO}_{3}$ & 69 \\
3 & $\mathrm{KO}_{\mathrm{Bu}}$ & 37 \\
4 & $\mathrm{NaHCO}_{3}$ & $\mathbf{9 8}$ \\
5 & $\mathrm{KOH}_{2}$ & 41 \\
6 & $\mathrm{KHCO}_{3}$ & 93 \\
7 & $\mathrm{NaO}^{\mathrm{Bu}}$ & 72 \\
8 & $\mathrm{Na}_{2} \mathrm{CO}_{3}$ & 27 \\
9 & $\mathrm{Et}_{3} \mathrm{~N}$ & 93 \\
10 & $\mathrm{CH}_{3} \mathrm{COONa}_{1}$ & 24 \\
11 & $\mathrm{Without} \mathrm{base}$ & $\mathrm{n} . \mathrm{r}$ \\
\hline
\end{tabular}

${ }^{a}$ Reaction Conditions: aldehyde $(1 \mathrm{mmol}) ; \mathrm{NH}_{2} \mathrm{OH} \cdot \mathrm{HCl}$ (1mmol), base $(1 \mathrm{mmol})$; [Ru-NHC] catalyst $3 \mathrm{a}(0.5 \mathrm{~mol} \%)$ under $\mathrm{N}_{2}$, reflux for $8 \mathrm{~h} ;{ }^{b}$ Conversion determined by GC.

In order to optimize the catalyst loading, the amidation reaction was performed at catalyst loading in the range of $0.15-0.5 \mathrm{~mol} \%$ (Table 3 ). The reactions proceed with high conversion of benzaldehyde to benzamide when $0.5 \mathrm{~mol} \%$ is used. Further, the catalyst works well with low catalyst loading of $0.15 \mathrm{~mol} \%$ and $0.25 \mathrm{~mol} \%$, showing a yield of $68-77 \%$ and $73-84 \%$ respectively. Since, the isolated yields are good with appreciable turnover numbers when catalyst loading is $0.5 \mathrm{~mol} \%$. Catalyst with phenyl wingtip substituent exhibits higher activity when compared to others. Hence, the order of catalytic activity with respect to different wingtip substituents has been observed as $\mathbf{3 a}>\mathbf{3 d}>\mathbf{3 b}>\mathbf{3 c}$.
In order to ensure the generality of this finding, a range of aromatic aldehydes were converted to amides using catalyst 3a under the optimized condition. A broad range of amides were successfully synthesized with good to high isolated yields using the above optimized protocol. The results collected from the catalytic reactions are listed in Table 4 . The electron donating groups like $-\mathrm{CH}_{3},-\mathrm{OCH}_{3}$ and $-\mathrm{OH}$ on benzaldehyde alters the reaction and the corresponding amides were obtained in excellent yields of 93, 96 and $91 \%$ respectively (Table 4, Entries 2, 3, 4) and gave slightly lower yields compared with benzaldehyde (Table 4, Entry 1). On the other hand, electron withdrawing substituents, such as $-\mathrm{NO}_{2},-\mathrm{Cl}$ and $-\mathrm{Br}$ substituents also offer good yields (Table 4, Entries 6, 7, 8). The reaction of napthaldehyde in presence of toluene afforded the desired amide product in excellent yield (Table 4, Entry 8). The catalyst shows good catalytic activity for the conjugated aldehyde such as, cinnamaldehyde which was converted to the corresponding conjugated amides in $92 \%$ yield (Table 4, Entry 9). Interestingly, the amidation reaction with aliphatic aldehyde gave good yield (Table 4, Entry 10).

Further, to explore the scope of the catalyst, a range of heteroaromatic aldehydes were converted to primary heteroaromatic amides using catalyst $\mathbf{3 a}$ under the optimized condition. Results show all the aldehydes reacted well and resulted in excellent yield of the products (Table 5). The complex efficiently catalyzes the reaction of thiophene and substituted thiophene aldehydes to their corresponding carboxamides in good yield (Table 5, Entry 1,2). The pyridine carbaldehydes yielded the corresponding amide product in $76 \%$ and $81 \%$ yields (Table 5, Entries 3, 4). Moderate yields of amide products could be obtained for the reaction involving indole-2-carbaldehyde and

Table 3. Effect of catalyst screening on amidation of benzaldehyde to benzamide catalyzed by $[\mathrm{Ru}-\mathrm{NHC}]$ complexes $\mathbf{3 a - 3} \mathbf{d}^{a}$.

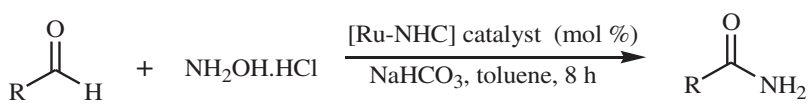

\begin{tabular}{lccccc}
\hline Entry & Catalyst & Amount of catalyst (mol \%) & $\operatorname{TON}^{b}$ & ${\text { TOF }\left(\mathrm{h}^{-1}\right)^{c}}^{(\%)}$ conversion $^{b}$ \\
\hline $\mathbf{1}$ & 3a & $\mathbf{0 . 1 5 / 0 . 2 5 / 0 . 5}$ & $\mathbf{5 1 3 / 3 3 2 / 1 9 6}$ & $\mathbf{6 4 / 4 2 / 2 5}$ & $\mathbf{7 7 / 8 3 / 9 8}$ \\
2 & 3b & $0.15 / 0.25 / 0.5$ & $493 / 336 / 174$ & $62 / 42 / 22$ & $74 / 84 / 87$ \\
3 & 3c & $0.15 / 0.25 / 0.5$ & $413 / 292 / 162$ & $52 / 37 / 20$ & $62 / 73 / 81$ \\
4 & 3d & $0.15 / 0.25 / 0.5$ & $453 / 296 / 178$ & $57 / 37 / 22$ & $68 / 74 / 89$
\end{tabular}

${ }^{a}$ Reaction Conditions: aldehyde $(1 \mathrm{mmol}), \mathrm{NH}_{2} \mathrm{OH} \cdot \mathrm{HCl}(1 \mathrm{mmol}), \mathrm{NaHCO}_{3}(1 \mathrm{mmol}),[\mathrm{Ru}-$ NHC] catalyst 3a-3d $(0.15-0.5 \mathrm{~mol} \%)$ under $\mathrm{N}_{2}$ reflux for $8 \mathrm{~h} .{ }^{b}$ Turnover number $(\mathrm{TON})=$ $(\mathrm{mmol}$ of product $) /\left(\mathrm{mmol}\right.$ of catalyst) after time $\mathrm{t} ;{ }^{c}$ Turnover frequency $(\mathrm{TOF})=\mathrm{TON} / \mathrm{time}$ (h); ${ }^{d}$ Conversion determined by GC. 
Table 4. One pot synthesis of amides from aldehydes catalyzed by [Ru-NHC] complex $\mathbf{3} \mathbf{a}^{a}$.

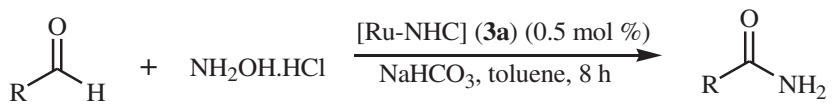

\begin{tabular}{|c|c|c|c|c|}
\hline Entry & Aldehyde & Amide & $\operatorname{TOF}\left(\mathrm{h}^{-1}\right)^{b}$ & $(\%)$ conversion $^{c}$ \\
\hline 1 & & & 25 & 98 \\
\hline 2 & & & 23 & 93 \\
\hline 3 & & & 24 & 96 \\
\hline 4 & & & 23 & 91 \\
\hline 5 & & & 22 & 89 \\
\hline 6 & & & 24 & 94 \\
\hline 7 & & & 23 & 93 \\
\hline 8 & & & 25 & 99 \\
\hline 9 & & & 23 & 92 \\
\hline 10 & & & 20 & 81 \\
\hline
\end{tabular}

${ }^{a}$ Reaction Conditions: aldehyde $(1 \mathrm{mmol}), \mathrm{NH}_{2} \mathrm{OH} \cdot \mathrm{HCl}(1 \mathrm{mmol}), \mathrm{NaHCO}_{3}(1 \mathrm{mmol}),[\mathrm{Ru}-\mathrm{NHC}]$ catalyst 3a $(0.5 \mathrm{~mol} \%)$ under $\mathrm{N}_{2}$ reflux for $8 \mathrm{~h} ;{ }^{b}$ Turnover frequency $(\mathrm{TOF})=$ TON/time $(\mathrm{h}) ;{ }^{c}$ Conversion determined by GC.

pyrrole-2-carbaldehyde (Table 5, Entries 5, 6). However, when furan-2-carbaldehyde was used as a substrate, higher yield was obtained (Table 5, Entry 7). It is worth noting that by-products such as nitriles or carboxylic acids are not observed in this protocol, indicating that this reaction differs from the Beckmann rearrangement.

Further, we believe that the catalytic transformation proceeds via the oxidative addition of the aldoxime
$\mathrm{N}-\mathrm{OH}$ bond to $\mathrm{Ru}(\mathrm{II})-\mathrm{NHC}$ complex, followed by nucleophilic attack on the coordinated imine, and then $\beta$-elimination of cyclometalated compound, and finally reductive elimination to give the amide according to the proposed mechanism by Crabtree and his coworkers. ${ }^{44 a}$ In this reaction, water cannot be eliminated as a by-product indicating the absence of nitrile products. The present $[\mathrm{Ru}-\mathrm{NHC}]$ catalyst is more efficient in amidation reaction than the reported ruthenium(II) 
Table 5. One pot synthesis of amides from heteroaromatic aldehydes catalyzed by [Ru-NHC] complex $\mathbf{3 a}^{a}$.

\begin{tabular}{|c|c|c|c|c|}
\hline Entry & Aldehyde & Amide & $\operatorname{TOF}\left(\mathrm{h}^{-1}\right)^{b}$ & $(\%)$ conversion $^{c}$ \\
\hline 1 & 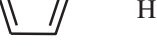 & & 24 & 97 \\
\hline 2 & & & 22 & 87 \\
\hline 3 & & & 19 & 76 \\
\hline 4 & & & 20 & 81 \\
\hline 5 & & & 18 & 73 \\
\hline 6 & $\mathrm{H}$ & & 20 & 79 \\
\hline 7 & & & 22 & 88 \\
\hline
\end{tabular}

${ }^{a}$ Reaction Conditions: aldehyde $(1 \mathrm{mmol}), \mathrm{NH}_{2} \mathrm{OH} \cdot \mathrm{HCl}(1 \mathrm{mmol}), \mathrm{NaHCO}_{3}(1 \mathrm{mmol}),[\mathrm{Ru}-\mathrm{NHC}]$ catalyst 3a $(0.5 \mathrm{~mol} \%)$ under $\mathrm{N}_{2}$ reflux for $8 \mathrm{~h} ;{ }^{b}$ Turnover frequency (TOF) $=$ TON/time (h); ${ }^{c}$ Conversion determined by GC.

complexes in terms of reaction time, catalyst loading and isolated yields. ${ }^{44 a, 53}$

\section{Conclusions}

A new series of imidazolium salts (1a-d) was designed and successfully used for the preparation of ruthenium(II) complexes bearing neutral bidentate ligands of $N$-heterocyclic carbene and pyridine donor moiety. The ruthenation was accomplished by metalation with $\mathrm{Ag}_{2} \mathrm{O}$ to form intermediate silver carbene complexes and subsequent transmetalation with $\left[\mathrm{RuHCl}(\mathrm{CO})\left(\mathrm{PPh}_{3}\right)_{3}\right]$. Promising yields were obtained. The $[\mathrm{Ru}-\mathrm{NHC}]$ complexes (3a-d) displayed excellent stability toward air and moisture which are the additional advantages for a better catalyst. Based on the spectral results, an octahedral geometry was assigned for all the complexes. The catalytic ability of the present system for the conversion of aldehydes to amides has been studied and the conversions are found to be excellent. Notably, the complex 3a was found to be a very efficient and versatile catalyst towards amidation of a wide range of aldehydes.

\section{Supplementary Information (SI)}

Representative NMR $\left({ }^{1} \mathrm{H},{ }^{13} \mathrm{C},{ }^{31} \mathrm{P}\right)$ and ESI-MS spectra of ligand and complexes (Figures S1-S18) are given in the supporting information, available at www.ias.ac.in/ chemsci.

\section{Acknowledgements}

The authors express their sincere thanks to Department of Science and Technology, New Delhi, for financial support for this work under the DST-FAST TRACK Scheme (No. SR/FT/CS-66/2011). One of the authors (MN) thanks DST-SERB for the award of fellowship.

\section{References}

1. Lin J C Y, Huang R T W, Lee C S, Bhattacharyya A, Hwang W S and Lin I J B 2009 Chem. Rev. 1093561

2. Crabtree R H 2005 J. Organomet. Chem. 6905451

3. Dragutan V, Dragutan I, Delaude L and Demonceau A 2007 Coord. Chem. Rev. 251765

4. (a) Díez-González S, Marion $\mathrm{N}$ and Nolan S P 2009 Chem. Rev. 109 3612; (b) Nirmala M and 
Viswanathamurthi P 2016 J. Chem. Sci. 128 9; (c) Roymahapatra G, Samanta T, Seth S K, Mahapatra A, Chattopadhyay S K and Dinda J 2015 J. Chem. Sci. 127 1057; (d) Gangwar M K, Kalita A C and Ghosh P 2014 J. Chem. Sci. 1261557

5. Hahn F E and Jahnke M C 2008 Angew. Chem., Int. Ed. 473122

6. Herndon J W 2010 Coord. Chem. Rev. 254103

7. Nolan S P 2010 Acc. Chem. Res. 14491

8. Velazquez H D and Verpoort F 2012 Chem. Soc. Rev. 41 7032

9. Würtz S and Glorius F 2008 Acc. Chem. Res. 411523

10. Herrmann W A 2002 Angew. Chem., Int. Ed. 411290

11. (a) Arnold P L and Pearson S 2007 Coord. Chem. Rev. 251 596; (b) Arslan H, Özdemır I, Vanderveer D, Demır S and Cetınkaya B 2009 J. Coord. Chem. 62 2591; (c) Özdemir I, Yiğit M, Yiğit B, Çetinkaya B and Çetinkaya E 2007 J. Coord. Chem. 602377

12. Bouffard J, Keitz B K, Tonner R, Guisado-Barrios G, Frenking G, Grubbs R H and Bertrand G 2011 Organometallics $\mathbf{3 0} 2617$

13. Chianese A R, Kovacevic A, Zeglis B M, Faller J W and Crabtree R H 2004 Organometallics 232461

14. Guisado-Barrios G, Bouffard J, Donnadieu B and Bertrand G 2010 Angew. Chem., Int. Ed. 494759

15. Han Y and Huynh H V 2007 Chem. Commun. 1089

16. Han Y, Lee L J and Huynh H V 2009 Organometallics 282778

17. Han Y and Huynh H V 2011 Dalton Trans. 402141

18. Lavallo V, Canac Y, Präsang C, Donnadieu B and Bertrand G 2005 Angew. Chem. Int. Ed. 445705

19. Mathew P, Neels A and Albrecht M 2008 J. Am. Chem. Soc. 13013534

20. Melaimi M, Soleilhavoup M and Bertrand G 2010 Angew. Chem., Int. Ed. 498810

21. (a) Ung G and Bertrand G 2011 Chem. -Eur. J. 17 8269; (b) Martin D, Melaimi M, Soleilhavoup M and Bertrand G 2011 Organometallics 305304

22. Hopkinson M N, Richter C, Schedler M and Glorius F 2014 Nature $\mathbf{5 1 0} 485$

23. (a) Kuhl O 2007 Chem. Soc. Rev. 36 592; (b) Lee H M, Lee C C and Cheng P Y 2007 Curr. Org. Chem.11 1491; (c) Normand A T and Cavell K J 2008 Eur. J. Inorg. Chem. 278 12800; (d) Yaşar S, Çekirdek S and Özdemir I 2014 J. Coord. Chem. 67 1236; (e) Pozo C D, Iglesias $\mathrm{M}$ and Sanchez F 2011 Organometallics 302180

24. (a) Wang C Y, Liu Y H, Peng S M and Liu S T 2006 J. Organomet. Chem. 691 4012; (b) Danopoulos A A, Winston S and Hursthouse M B 2002 J. Chem. Soc., Dalton Trans. 3090; (c) Stylianides N, Danoupolos A A and Tsoureas N 2005 J. Organomet. Chem. 690 5948; (d) Wang X, Liu S, Weng L H and Jin G X, Chem. Eur. J. 13188

25. (a) Mas-Marz E, Sana M and Peris E 2005 Inorg. Chem. 44 9961; (b) Wang C Y, Fu C F, Liu Y H, Peng S M and Liu S T 2007 Inorg. Chem. 465779

26. (a) Wang X, Liu S and Jin G X 2004 Organometallics 23 6002; (b) Winston S, Stylianides N, Tulloch A A D, Wright J A and Danoupolos A A 2004 J. Organomet. Chem. 232813
27. (a) Magill A M, McGuinness D S, Cavell K J, Britovsek G J P, Gibson V C, White A J P, Williams D J, White A J and Skelton B W 2001 J. Organomet. Chem. 617; (b) Wang X, Liu S, Weng L H and Jin G X 2006 Organometallics 253565

28. Tulloch A A D, Danopoulos A A, Kleinhenz S, Light M E, Hurthouse M B and Eastham G 2001 Organometallics 202027

29. Tulloch A A D, Danopoulos A A, Winston S, Kleinhenz S and Eastham G 2000 J. Chem. Soc., Dalton Trans. 4499

30. Dugger R W, Ragan J A and Ripin D H B 2005 Org. Process Res. Dev. 9253

31. Chen H, He M, Wang Y, Zhai L, Cui Y, Li Y, Zhou H, Hong X and Deng Z 2011 Green Chem. 132723

32. Curtius T 2006 Berichte derdeutschen chemischen Gesellschaft 353226

33. Gunanathan C, Ben-David Y and Milstein D 2007 Science $\mathbf{3 1 7} 790$

34. Shen B, Makley D M and Johnston J N 2010 Nature 465 1027

35. Sheldon R A 1994 Chem. Tech. 38

36. (a) Mabermann C E 1991 In Encyclopedia of Chemical Technology Vol. 1 (New York: Wiley) p.251; (b) Lipp D 1991 In Encyclopedia of Chemical Technology vol. 1 (New York: Wiley) p.266; (c) Opsahl R 1991 In Encyclopedia of Chemical Technology Vol. 2 (New York: Wiley) p.346

37. Constable D J C, Dunn P J, Hayler J D, Humphrey G R, Leazer J L, Linderman R J, Lorenz K, Manley J, Pearlman B A, Wells A, Zaks A and Zhang T Y 2007 Green Chem. 9411

38. (a) Tfouni E, Krieger M, Mcgarvey B R and Franco D W 2003 Coord. Chem. Rev. 236 57; (b) Coe B J and Glenwright S 2000 J. Coord. Chem. Rev. 203 5; (c) Batista A A, Pereira C, Wohnrath K, Queiroz S L, Santos R H A and Gambardella M T P 1999 Polyhedron 18 2079; (d) Poelhsitz G V, Araujo M P, Oliveira L A A, Queiroz S L, Ellena J, Castellano E E, Ferreira A G and Batista A A 2002 Polyhedron 21 2221; (e) Bastista A A, Pereira C, Queiroz S L, Oliverira L A A, Santos R H A and Gambardella M T P 1997 Polyhedron 16 927; (f) Gianferrara T, Serli B, Zangrando E, Lengo E and Alessio E 2005 New J. Chem. 29 895; (g) Serli B, Zangrando E, Lengo E, Mestroni G, Yellowlees L and Alessio E 2002 Inorg. Chem. 41 4033; (h) Videla M, Jacinto J S, Baggio R, Garland M T, Singh P, Kaim W, Slep L D and Olabe J A 2006 Inorg. Chem. 45 8608; (i) Hirano T, Ueda K, Mukaida M, Nagao H and Oi T 2001 J. Chem. Soc., Dalton Trans. 2341; (j) Borges S S, Davanzo C U, Castellano E E, Schpector J, Silva S C and Franco D W 1998 Inorg. Chem. 37 2670; (k) Fortney C F and Shepherd R E 2004 Inorg. Chem. Commun. 71065

39. (a) Lebel H and Paquet V 2004 Organometallics 23 1187; (b) Kuwata S, Kura S and Ikariya T 2007 Polyhedron 26 4659; (c) Katho A, Opre Z, Laurenczy G and Joo F 2003 J. Mol. Catal. A: Chem. 204 143; (d) Wilson S T and Osborn J A 1971 J. Am. Chem. Soc. 933068

40. (a) Nørdstrom L U, Vogt H and Madsen R 2008 J. Am. Chem. Soc. 130 17672; (b) Ghosh S C, Muthaiah S, Zhang Y, Xu X and Hong S H 2009 Adv. Synth. Catal. 
351 2643; (c) Zhang Y, Chen C, Ghosh S C, Li Y and Hong S H 2010 Organometallics 291374

41. Muthaiah S, Ghosh S C, Jee J E, Chen C, Zhang J and Hong S H 2010 J. Org. Chem. 753002

42. Field L, Barnett P, Shumaker S H and Marshall W S 1961 J. Am. Chem. Soc. 831983

43. Sharma S K, Bishopp S D, Allen C L, Lawrence R, Bamford B J, Lapkin A A, Plucinski P, Watson R J and Williams J M J 2011 Tetrahedron Lett. 524252

44. (a) Gnanamgari D and Crabtree R H 2009 Organometallics 28 922; (b) Hull J F, Hilton S T and Crabtree R H 2010 Inorg. Chim. Acta 363 1243; (c) Owston N A, Parker A J and Williams J M J 2007 Org. Lett. 93599

45. Barfoot C, Brooks G, Brown P, Dabbs S, Davies D T, Giordano I, Hennessy A, Jones G, Markwell R, Miles T, Pearson N and Smethurst C A 2010 Tetrahedron Lett. 51 2685

46. (a) Owston N A, Parker A J and Williams J M J 2007 Org. Lett. 9 73; (b) Saidi O, Bamford M J, Blacker A J, Lynch J, Marsden S P, Plucinski P, Watson R J and Williams J M J 2010 Tetrahedron Lett. 515804
47. Park S, Choi Y, Han H, Yang S H and Chang S 2003 Chem. Commun. 1936

48. Allen C L, Burel C and Williams J M J 2010 Tetrahedron Lett. 512724

49. (a) Gridnev A A and Mihaltseva I M 1994 Synth. Commun. 24 1547; (b) Liu J, Chen J, Zhao J, Zhao Y, Li L and Zhang H 2003 Synthesis 17 2661; (c) Sreedhar B, Shiva Kumar K B, Srinivas P, Balasubrahmanyam V and Venkanna G T 2007 J. Mol. Catal. A: Chem. 265 183

50. Ahmed N, Levison S J, Robinson S D and Uttley M F 1974 Inorg. Synth. 1548

51. (a) Loch J A, Albrecht M, Peris E, Mata J, Faller J W and Crabtree R H 2002 Organometallics 21 700; (b) Frey G D, Schutz J, Herdtweck E and Hermann W A 2005 Organometallics 24 4416; (c) Kaufhold O, Hahn F E, Pape T and Hepp A 2008 J. Organomet. Chem. 693 3435

52. El-Shahawi M S and Shoair A F 2004 Spectrochim. Acta A 60121

53. Tyagi D, Rai R K, Dwivedi A D, Mobin S M and Singh S K 2015 Inorg. Chem. Front. 2116 